\title{
Incidence of Stenocarpella maydis Ear Rot of Corn Under Crop Rotation Systems
}

\author{
B. C. Flett and N. W. McLaren, ARC - Grain Crops Institute, Private Bag X1251, Potchefstroom, 2520, Republic \\ of South Africa; and F. C. Wehner, Department of Microbiology and Plant Pathology, University of Pretoria, Preto- \\ ria, 0002, Republic of South Africa
}

\begin{abstract}
Flett, B. C., McLaren, N. W., and Wehner, F. C. 2001. Incidence of Stenocarpella maydis ear rot of corn under crop rotation systems. Plant Dis. 85:92-94.

The efficacy of crop rotation in reducing corn ear rot caused by Stenocarpella maydis in reduced and conventional tillage systems was determined over five and four seasons, respectively, at two sites in South Africa. Stenocarpella ear rot and S. maydis was isolated from kernels more frequently in monoculture corn and crop rotation where corn was planted for two consecutive seasons than where monoculture corn was interrupted by a rotation crop. Surface stubble mass, and consequently inoculum pressure, were affected similarly by crop rotation. Positive linear relationships were recorded between Stenocarpella ear rot incidence, surface stubble mass, and pycnidial counts. Wheat, soybean, and peanut were the most effective, and sunflower the least effective, rotation crops for reducing $S$. maydis ear rot.
\end{abstract}

Additional keywords: Diplodia maydis

The ear rot pathogen of corn (Zea mays L.), Stenocarpella maydis (Berk.) Sutton, occurs worldwide wherever the crop is cultivated (11). Ear rot results in yield losses, reduced grain quality (8), and mycotoxicity (10).

S. maydis overwinters on host residues (7). The successful control of plant diseases by crop rotation depends on the ability of the pathogen to infect other hosts and the time needed for inoculum reduction, which is related to the ability of the pathogen to survive in the field (2). S. maydis is unable to colonize crop plants other than corn (3). The only other reported host of $S$. maydis is an Arundinaria spp. (11). $S$. maydis therefore depends on corn surface stubble for survival (7). Flett (4) reported that $S$. maydis spore viability decreased significantly over 24 months irrespective of numbers of pycnidia. This study suggests that inoculum of $S$. maydis should be significantly reduced within two seasons.

Due to the requirements for survival and inoculum production, crop rotation appears to be effective for control of $S$. maydis ear rot. The objective of this study was to determine the incidence of $S$. maydis in crop rotation with corn.

\section{MATERIALS AND METHODS}

Field trials were carried out in the Free State Province of South Africa at Bethle-

Corresponding author: B. C. Flett

E-mail: Brad@igg2.agric.za

Accepted for publication 13 October 2000.

Publication no. D-2000-1109-01R

(c) 2001 The American Phytopathological Society hem $\left(27^{\circ} 14^{\prime} \mathrm{S}, 27^{\circ} 55^{\prime} \mathrm{E}\right)$ from $1992-93$ to 1996-97 and at Viljoenskroon $\left(28^{\circ} 12^{\prime} \mathrm{S}\right.$, $28^{\circ} 17^{\prime} \mathrm{E}$ ) from $1993-94$ to $1996-97$. Soil type at Bethlehem was an Avalon and at Viljoenskroon was a Clovelly. Crop rotations at Viljoenskroon included two seasons of corn followed by one season of sunflower (Helianthus annuus), peanut (Arachis hypogaea), or soybean (Glycine max). Monoculture corn was included as a control. At Bethlehem, one crop rotation included drybeans (Phaseolus spp.) followed by winter-spring wheat (Triticum spp.) followed by fallow until the subsequent spring when corn was planted. Other rotations were corn followed by soybean and corn monoculture as a control treatment. Three sets of each experiment, the first initiated in the 1991-92 season, were planted at each locality to ensure that the same treatments were sampled each season. At Viljoenskroon, plots were prepared using minimum tillage, except during the 1996-97 season, when plots were disced to apply lime to readjust soil acidity. Conventional tillage was applied at Bethlehem. Experimental designs were a randomized block design with plot sizes of $20 \times 50 \mathrm{~m}$ and $9 \times 25 \mathrm{~m}$, with three and four replicates at Viljoenskroon and Bethlehem, respectively. Plant populations were 22,000 and 22,500 at Viljoenskroon and Bethlehem, respectively. Susceptible corn hybrids adapted to each locality were planted. Weed and pest control and fertilization were applied at each locality according to standard field management practices.

Prior to harvest, 100 corn plants from the two center rows of each plot were sampled. S. maydis-infected ears were counted and expressed as a percentage of total ears discolored. The entire sample was then shelled. A 200-kernel sample from each replicate of each treatment was surfacedisinfested for $3 \mathrm{~min}$ in $3.5 \% \mathrm{NaOCl}$ and plated on half-strength malt extract agar (Oxoid Ltd., Basingstoke, Hampshire, England). After 2 days, fungal colonies were transferred to a corn kernel medium containing $10 \mathrm{~g}$ of ground corn kernels, $12 \mathrm{~g}$ of agar, and distilled water to make 1 liter. Cultures were incubated for 14 days under black light at $28^{\circ} \mathrm{C}$. S. maydis was identified by pycnidial and spore morphology (11).

At harvest during each season, four samples of surface stubble from $1,296 \mathrm{~cm}^{2}$ of soil surface were collected from each experimental plot, rinsed in running tap water, air-dried, and weighed. Corn stubble mass was expressed as $\mathrm{gm}^{-2}$. Five corn stubble segments were selected to determine the number of $S$. maydis pycnidia in each of five $0.25 \mathrm{~cm}^{2}$ squares on the surface of each segment.

Data were subjected to analysis of variance (Statgraphics ver. 2.6) using log transformations. Significant differences between crop rotations were determined by least significant difference at $P<0.05$. Linear regression was used to analyze the relationship between surface stubble mass, $S$. maydis inoculum, and disease incidence.

\section{RESULTS}

Despite low incidence of ear rot at Viljoenskroon, crop rotation and season had a highly significant effect on incidence of $S$. maydis ear rot (Table 1). No significant season by crop rotation interaction was recorded $(P=0.12)$. In all cases where corn cultivation was continuous for more than a single season, $S$. maydis ear rot incidence increased from 1.1 to $2.0 \%$ where corn was alternated with sunflower, soybean, or peanut to 2.6 to $5.6 \%$. Sunflower was the least effective rotation crop in reducing $S$. maydis ear rot. This is indicated by a significant reduction in mean ear rot incidence in the soybean-corn-corn $(2.6 \%)$ and peanut-corn-corn $(3.3 \%)$ systems compared with sunflower-corn-corn $(5.3 \%)$.

The mean frequency of corn kernels from which S. maydis was isolated was highly correlated with $S$. maydis ear rot incidence $(r=0.84, P<0.01)$. However, the differences between the 2-year-corn, 1year-alternative crop systems were less distinct than ear rot incidence, indicating that a large percentage of the infected kernels were asymptomatic (Table 1). An 
exception was soybean, which was the only crop in a 2-year corn cycle that was associated with reduced ear rot incidence (2.6\% compared with 5.3 and $3.3 \%$ for sunflower and peanut, respectively) and kernel isolation frequency (5.6\% compared with 11.9 and $12.1 \%$ for sunflower and peanut, respectively).

Surface stubble mass yielded a highly significant crop rotation by season interaction $(P=0.000)$ (Table 2). With the exception of the 1996-97 season, which was disced, the overall tendency was for stubble mass to be high in plots with continuous corn cultivation (4.2 to $30.7 \mathrm{gm}^{-2}$ ), whether in monoculture or for two consecutive seasons before an alternative crop. However, within-season differences were not consistent. Crop rotation yielded significantly less stubble per plot (0 to 2.3 $\mathrm{gm}^{-2}$ ).

Stenocarpella ear rot incidence was significantly related to stubble mass per plot during the 1993-94 and 1994-95 seasons (Fig. 1) but not the 1995-96 and 1996-97 seasons. Similarly, isolation of $S$. maydis from kernels was significantly related to surface stubble mass during 1993-94, 1994-95, and 1995-96 seasons (Fig. 2). Isolation of $S$. maydis from kernels was highly significantly related to the product of stubble mass and pycnidial counts (Fig. 3). At Bethlehem, where plots were plowed, S. maydis ear rot incidence was extremely low (Table 3 ). An exception was the 1996-97 season, where the tendency for $S$. maydis ear rot incidence in monoculture maize was higher than in crop rotations.

\section{DISCUSSION}

This study confirms previous results on the effect of crop rotation on incidence of $S$. maydis infection in corn $(1,9)$. Results indicated that this practice is only effective in reduced tillage or in plow systems where monoculture corn is practiced for an extended period. Crop rotation appears to affect incidence of $S$. maydis ear rot by extending the period for stubble breakdown, thus reducing inoculum production. $S$. maydis is unable to colonize crop plants other than corn, and hence debris from these crops could not serve as an inoculum

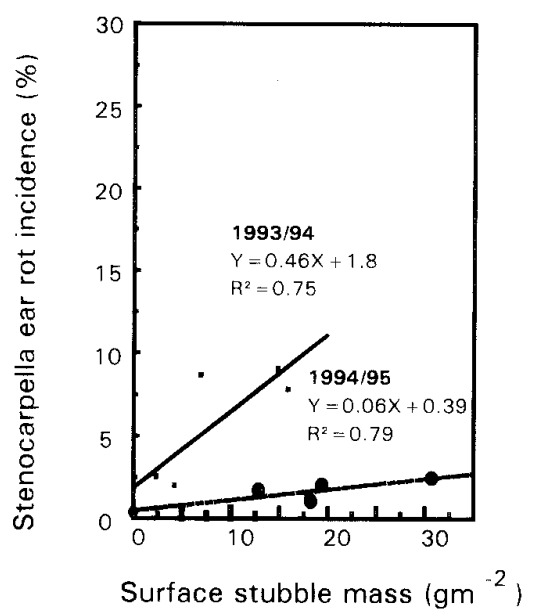

Fig. 1. Relationship between surface stubble mass $\left(\mathrm{gm}^{-2}\right)$ and Stenocarpella ear rot incidence $(\%)$.

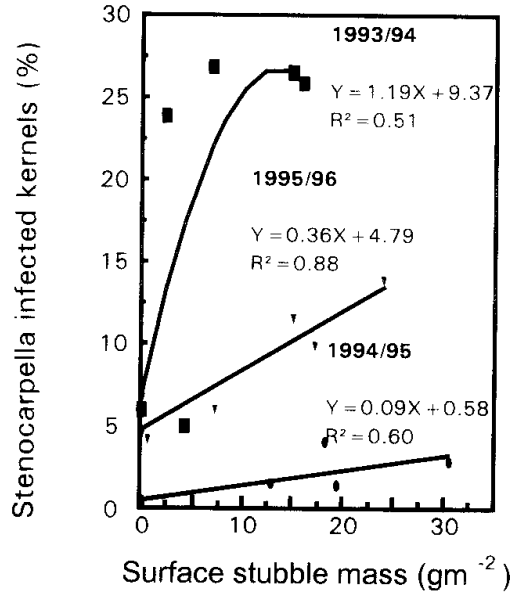

Fig. 2. Relationship between surface stubble mass $\left(\mathrm{gm}^{-2}\right)$ and Stenocarpella-infected kernels $(\%)$.

Table 2. Surface corn stubble mass collected from different crop rotations at Viljoenskroon from 1993-94 to 1996-97w

\begin{tabular}{|c|c|c|c|c|c|}
\hline \multirow[b]{2}{*}{$\begin{array}{l}\text { Crop } \\
\text { rotations }^{\mathrm{z}}\end{array}$} & \multicolumn{5}{|c|}{ Surface stubble mass $\left(\mathrm{gm}^{-2}\right)^{\mathrm{x}, \mathrm{y}}$} \\
\hline & 1993-94 & 1994-95 & $1995-96$ & 1996-97 & $\begin{array}{c}\text { Treatment } \\
\text { mean }\end{array}$ \\
\hline $\mathrm{C} / \mathrm{C} / \mathrm{C}$ & $6.9 \mathrm{def}$ & $12.9 \mathrm{cde}$ & $15.0 \mathrm{bcd}$ & $0.1 \mathrm{f}$ & 8.7 \\
\hline $\mathrm{Sf} / \mathrm{C} / \mathrm{C}$ & $14.8 \mathrm{bcd}$ & $19.4 b c$ & $24.0 \mathrm{ab}$ & $0.2 \mathrm{f}$ & 14.6 \\
\hline $\mathrm{Sb} / \mathrm{C} / \mathrm{C}$ & $4.2 \mathrm{ef}$ & $30.7 \mathrm{a}$ & $7.2 \mathrm{def}$ & $0.7 \mathrm{f}$ & 10.7 \\
\hline $\mathrm{P} / \mathrm{C} / \mathrm{C}$ & $15.8 \mathrm{bcd}$ & $18.3 \mathrm{bc}$ & $17.1 \mathrm{bcd}$ & $11.4 \mathrm{c}$ & 15.7 \\
\hline $\mathrm{C} / \mathrm{Sf} / \mathrm{C}$ & $2.3 \mathrm{ef}$ & $0 \mathrm{f}$ & $0 \mathrm{f}$ & $2.6 \mathrm{ef}$ & 1.2 \\
\hline $\mathrm{C} / \mathrm{Sb} / \mathrm{C}$ & $0 \mathrm{f}$ & $0 \mathrm{f}$ & $0 \mathrm{f}$ & $1.2 \mathrm{f}$ & 0.4 \\
\hline $\mathrm{C} / \mathrm{P} / \mathrm{C}$ & $0 \mathrm{f}$ & $0 \mathrm{f}$ & $0 \mathrm{f}$ & $0.8 \mathrm{f}$ & 0.2 \\
\hline Season mean & 6.3 & 11.6 & 9.1 & 2.4 & 7.4 \\
\hline
\end{tabular}

${ }^{\mathrm{w}}$ Log transformations were used for all data.

${ }^{x}$ Means within and across columns followed by different letters differ significantly at $P<0.05$ according to least significant difference test.

${ }^{y}$ Surface stubble for $1,296 \mathrm{~cm}^{2}$ samples was randomly collected, washed, air-dried, weighed, and calculated as $\mathrm{gm}^{-2}$.

${ }^{\mathrm{z}}$ Rotation treatment applied: $\mathrm{C}=$ corn, $\mathrm{Sf}=$ sunflower, $\mathrm{Sb}=$ soybean, $\mathrm{P}=$ peanut.

Table 1. Incidence of Stenocarpella ear rot in corn and percent kernels from which Stenocarpella maydis was isolated in crop rotations at Viljoenskroon from 1993-94 to 1996-97v

\begin{tabular}{|c|c|c|c|c|c|c|c|c|c|c|}
\hline \multirow[b]{2}{*}{$\begin{array}{l}\text { Crop } \\
\text { rotations }\end{array}$} & \multicolumn{5}{|c|}{ S. maydis-infected ears $(\%)^{\mathrm{w}, \mathrm{x}}$} & \multicolumn{5}{|c|}{ S. maydis isolation $(\%)^{y}$} \\
\hline & 1993-94 & 1994-95 & 1995-96 & 1996-97 & $\begin{array}{c}\text { Treatment } \\
\text { mean }\end{array}$ & 1993-94 & 1994-95 & 1995-96 & 1996-97 & $\begin{array}{c}\text { Treatment } \\
\text { mean }\end{array}$ \\
\hline $\mathrm{C} / \mathrm{C} / \mathrm{C}$ & 8.7 & 1.6 & 10.2 & 2.0 & $5.6 \mathrm{a}$ & 26.7 & 1.7 & 11.5 & 13.2 & $13.3 \mathrm{a}$ \\
\hline $\mathrm{Sf} / \mathrm{C} / \mathrm{C}$ & 9.1 & 2.0 & 6.9 & 3.2 & $5.3 \mathrm{a}$ & 26.3 & 1.5 & 13.8 & 5.8 & $11.9 \mathrm{abc}$ \\
\hline $\mathrm{Sb} / \mathrm{C} / \mathrm{C}$ & 2.0 & 2.4 & 4.6 & 1.6 & $2.6 \mathrm{~b}$ & 4.7 & 2.8 & 6.0 & 9.0 & $5.6 \mathrm{~cd}$ \\
\hline $\mathrm{P} / \mathrm{C} / \mathrm{C}$ & 7.8 & 1.0 & 2.9 & 1.4 & $3.3 \mathrm{~b}$ & 25.7 & 4.2 & 9.8 & 8.8 & $12.1 \mathrm{ab}$ \\
\hline $\mathrm{C} / \mathrm{Sf} / \mathrm{C}$ & 2.6 & 0.3 & 4.1 & 0.2 & $2.0 \mathrm{c}$ & 23.7 & 0.3 & 6.7 & 6.8 & $9.4 \mathrm{bcd}$ \\
\hline $\mathrm{C} / \mathrm{Sb} / \mathrm{C}$ & 1.7 & 0.0 & 2.2 & 0.6 & $1.1 \mathrm{c}$ & 5.7 & 0.5 & 4.2 & 3.5 & $3.5 \mathrm{~d}$ \\
\hline $\mathrm{C} / \mathrm{P} / \mathrm{C}$ & 1.6 & 0.8 & 1.7 & 1.0 & $1.3 \mathrm{c}$ & 5.2 & 0.5 & 4.5 & 6.7 & $4.2 \mathrm{~d}$ \\
\hline Season mean & $4.8 \mathrm{a}$ & $1.1 \mathrm{~b}$ & $4.7 \mathrm{a}$ & $1.4 \mathrm{~b}$ & & $16.8 \mathrm{a}$ & $1.6 \mathrm{c}$ & $8.1 \mathrm{~b}$ & $7.7 \mathrm{~b}$ & \\
\hline
\end{tabular}

$\mathrm{v}$ Log transformations were used for all data.

${ }^{\text {w }}$ Season and treatment means followed by different letters differ significantly at $P<0.05$ according to least significant difference test.

x $S$. maydis-infected ears were determined visually according to ear discoloration and presence of pycnidia.

y A random 200-kernel sample for each replicate was plated out on half-strength malt extract agar, incubated at $28^{\circ} \mathrm{C}$ for 48 h, and plated out on a ground kernel agar for identification.

${ }^{\mathrm{z}}$ Rotation treatment applied: $\mathrm{C}=$ corn, $\mathrm{Sf}=$ sunflower, $\mathrm{Sb}=$ soybean, $\mathrm{P}=$ peanut. 
Table 3. Incidence of Stenocarpella ear rot in corn and percent kernels from which Stenocarpella maydis was isolated in crop rotations at Bethlehem from $1992-93$ to $1996-97^{x}$

\begin{tabular}{|c|c|c|c|c|c|c|c|c|c|c|c|c|}
\hline \multirow[b]{2}{*}{$\begin{array}{l}\text { Crop } \\
\text { rotations }\end{array}$} & \multicolumn{6}{|c|}{ S. maydis-infected ears $(\%)^{y}$} & \multicolumn{6}{|c|}{ S. maydis isolation $(\%)^{\mathrm{z}}$} \\
\hline & 1992-93 & 1993-94 & 1994-95 & 1995-96 & 1996-97 & $\begin{array}{l}\text { Treatment } \\
\text { mean }\end{array}$ & 1992-93 & 1993-94 & 1994-95 & 1995-96 & 1996-97 & $\begin{array}{c}\text { Treatment } \\
\text { mean }\end{array}$ \\
\hline Corn-corn & 0 & 1.5 & 0 & 0.5 & 8.0 & 2.0 & 0.3 & 19.1 & 2.1 & 3.9 & 12.4 & 7.6 \\
\hline Soybeans-corn & 0 & 0 & 0 & 0.2 & 2.6 & 0.6 & 0.1 & 4.9 & 0.3 & 0 & 2.5 & 1.6 \\
\hline Wheat-corn & 0 & 0 & 1.3 & 1.0 & 2.9 & 1.0 & 0 & 1.3 & 0.8 & 0.3 & 1.4 & 0.7 \\
\hline Season mean & 0 & 0.5 & 0.4 & 0.6 & 4.5 & 1.2 & 0.1 & 8.4 & 1.0 & 1.4 & 5.4 & 3.3 \\
\hline
\end{tabular}

${ }^{x} \log$ transformations were used for all data.

y $S$. maydis-infected ears were determined visually according to ear discoloration and presence of pycnidia.

${ }^{\mathrm{z}}$ A random 200-kernel sample per each replicate was plated out on half-strength malt extract agar, incubated at $28^{\circ} \mathrm{C}$ for $48 \mathrm{~h}$, and plated out on a ground kernel agar for identification.

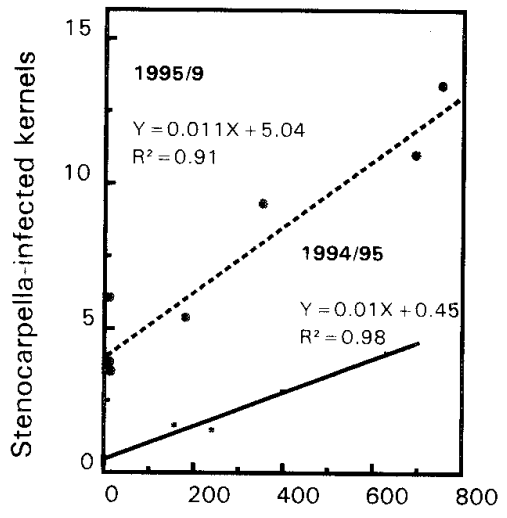

Surface stubble $x$ pycnidium counts

Fig. 3. Relationship between inoculum potential (surface stubble $\left[\mathrm{gm}^{-2}\right] \times$ pycnidium counts [pycnidia $\left.\mathrm{cm}^{-2}\right]$ ) and Stenocarpella-infected kernels $(\%)$.

maydis more readily than buried stubble (7). It thus appears that both reduced stubble mass per plot and reduced spore viability were instrumental in reducing ear rot incidence. This notion is supported by the extremely low levels of $S$. maydis ear rot at Viljoenskroon during 1996-97, when lime was incorporated into plots by discing, a process that also buried inoculum-bearing stubble, as well as by the absence of appreciable disease levels at Bethlehem except after five seasons of corn monoculture. Data also suggest that, under tillage systems that expedite stubble breakdown or promote stubble burial, monoculture may be practiced for a longer period before a rotation crop needs to be introduced. However, field comparisons under the same soil and environmental conditions are required to substantiate this, as well as the apparent inability of sunflower to reduce disease to the same extent as soybean and peanut.

Significant linear relationships between surface stubble mass and $S$. maydis ear rot have previously been reported $(5,6)$, but the relationship between pycnidial counts $x$ stubble mass and disease incidence is described here for the first time. This suggests that amount and quality of stubble and its concomitant ability to sustain production of pycnidia containing viable inoculum has a major effect on infection frequency. The absence of a relationship during 1996-97 could be attributed to low stubble mass as a result of discing of plots to incorporate lime, which buried the stubble. Variation not explained by regression analysis may be due to climatic factors affecting spore production, infection, and ramification by $S$. maydis. As these factors could influence the effect of crop rotation, they need to be investigated.

\section{ACKNOWLEDGMENTS}

We thank H. Loubser and A. Nel for allowing us to participate in these rotation studies. Further thanks to P. Minnie and R. Strauss for technical assistance.

\section{LITERATURE CITED}

1. Burrill, T. J., and Burrett, J. T. 1909. Ear rots of corn. Ill. Agric. Exp. Stn. Bull. 133.

2. Curl, E. A. 1963 . Control of plant diseases by crop rotation. Bot. Rev. 29:413-479.

3. Flett, B. C. 1991. Crop plants as hosts and non-hosts of Stenocarpella maydis. Phytophylactica 23:237-238.

4. Flett, B. C. 1993. The potential of crop rotation in the control of maize ear and stalk rots caused by Stenocarpella maydis. (Abstr.) Phytophylactica 25:184.

5. Flett, B. C., McLaren, N. W., and Wehner, F. C. 1998. Incidence of ear rot pathogens under alternating corn tillage practices. Plant Dis. 82:781-784.

6. Flett, B. C., and Wehner, F. C. 1991. Incidence of Stenocarpella and Fusarium cob rots in monoculture maize under different tillage systems. J. Phytopathol. 133:327-333.

7. Flett, B. C., Wehner, F. C., and Smith, F. 1992. Relationship between maize stubble placement in soil and survival of Stenocarpella maydis (Diplodia maydis). J. Phytopathol. 134:33-38.

8. Gevers, H. O. 1988. The ear rot epidemic. Proc. 8th South African Maize Breeding Symposium, Potchefstroom. Pages 77-80 in: Department of Agriculture and Water Supply. Tech. Comm. 238.

9. Koehler, B. 1959. Corn ear rots in Illinois. Ill Agric. Exp. Stn. Bull. 639.

10. Rheeder, J. P., Marasas, W. F. O., and Van Schalkwyk, D. J. 1993. Incidence of Fusarium and Diplodia species in naturally infected grain of South African maize cultivars: A follow up study. Phytophylactica 25:43-48.

11. Sutton, B. C., and Waterston, J. M. 1966. Diplodia maydis. CMI Descriptions of Pathogenic Fungi and Bacteria. No. 84, Commonw. Agric. Bur., Kew, Surrey, England. 